\title{
Философия
}

DOI: $10.17805 / g g z .2017 .3 .9$

\section{Экологический тренд как вектор развития}

\author{
М. И. КОЗЬЯКОВА \\ ВЫСШЕЕ ТЕАТРАЛЬНОЕ УЧИЛИЩЕ (ИНСТИТУТ) ИМ. М. С. ЩЕПКИНА
}

В статье рассматриваются проблемы экологии в контексте смены парадигм, перехода от классической к постклассической парадигме. Относимая к постмодернистской парадигме, экология культуры преодолевает базисные позиции постмодернистской методологии. Она выдвигает положения о концептуальной целостности, гармоничном сочетании человеческой деятельности и природы. Городское пространство, являясь примером окружающей человека среды, может рефлектироваться в качестве феномена экологии культуры. Рассмотрена методология его анализа, характеристики европейской урбанизированной среды.

Ключевые слова: экология; природа; культура; экология культуры; постмодерн; неклассическая парадигма; городская среда; публичное пространство

\section{Ecological Trend as a Vector of Development}

\author{
M. I. KOZYAKOVA
}

\section{S. SCHEPKIN HIGHER THEATRE SCHOOL (INSTITUTE)}

The article examines the problems of ecology in the context of the change of paradigms and the transition from classical to post-classical paradigm. Attributable to postmodern paradigm, the ecology of culture move beyond the basic viewpoints of postmodernist methodology. It puts forward statements on conceptual integrity, harmonious combination of human activities and nature. Urban space, being an example of human environment, can be reflected as a phenomenon of cultural ecology. The author discusses a methodology of its analysis and the features of the European urban environment.

Keywords: ecology; nature; culture; ecology of culture; postmodernity; non-classical paradigm; urban environment; public space

На современном этапе развития феномен окружающей человека среды оказывается чрезвычайно востребованным - более чем когда-либо ранее. Из разнообразных подходов, концепций, научных или же учебных программ изучения культуры отдельные концепты выходят на передний план, пользуются приоритетом в определенные временные периоды. Соответствующий конвенционализм наблюдается и в плане выбора доминант среди многочисленных дефиниций культуры. Представляется, что в настоящее время особое внимание получил так называемый экологический, средовой подход, в котором сама культура рассматривается как окружающая человека среда, а человеческая деятельность - как ее формирование. Актуализации данного тренда способствовали крайний динамизм и скорость происходящих изменений, разрывы социума, влекущие за собой утрату хорошо знакомого, традиционного мира. Возникают социальные формы и явления, не имевшие аналогов в прошлом, как не имеет их сегодня мировая экономика, привязанная к электронным деньгам, существующим в виде цифр на экранах компьютеров (Гидденс, 2004). К этому ряду относятся телекоммуникации и Интернет, глобализация и виртуалистика. 
Потеря стабильности, переход от динейного к ризомному типу развития сопровождается накоплением непредвиденных последствий, формирующих «общество риска», причем «риски, как и богатства, распределяются по классовой схеме, только в обратном порядке: богатства сосредотачиваются в верхних слоях, риски в низших » (Бек, 2001: 40). Аавинообразная трансформация традиционных доминант, определявших образ жизни и социальные практики нашего современника, планетарный характер воздействия человека на окружающую среду становится настолько фатальным, что на первый план с неизбежностью выдвигается вопрос экологической перспективы, обеспечивающей необходимый баланс между природой и человеком - тот баланс, который может служить сохранению жизни. Глобальная проблема современности защита окружающей среды, природы, приобретает особое значение в контексте гуманитарного дискурса. Экологический вектор побуждает оценивать человеческую деятельность, исходя не просто из критериев эффективности, но из этической и эстетической значимости ее результатов, способствующих органической целостности жизненной сферы.

Природа - явление сложное и многоплановое. В своем исходном качестве она принадлежит космическому универсуму как онтологическая данность, присутствует как материнское лоно, как матрица, необходимая для генерирования культурных форм. Являясь главным условием человеческого бытия, она воздействует на характер цивилизационных процессов, превращается в важный компонент социокультурного комплекса. Природа неизменно входит в картину мира: это происходит как на бытовом, повседневном, так и на аксиологически выделенном, мифологизированном или ритуализованном уровне. Семантическое поле этого первоначально эмотивно нейтрального феномена нагружается социальными, этическими, эстетическими, религиозными коннотациями.

Экологическое направление концентрируется на исследовании взаимосвязей человека и природы, их культурологического аспекта, на идеях гармоничного соединения природы, человека и техники, на поиске общечеловеческих этических и эстетических ценностей. Его актуализация связана с утверждением постнеклассической парадигмы, в которой объектом изучения современной науки становится не природа сама по себе, а взаимоотношение человека с природой. Современная наука, по словам В. Гейзенберга, «уже не занимает позиции наблюдателя природы, она осознает себя как частный вид взаимодействия человека с природой» (Гейзенберг, 1987: 304).

Человеческие практики всегда исторически и культурно обусловлены, и окружающая среда является как необходимым условием, так и их результатом, воплощением истории и культуры. Среда обитания человека - это не только природа, но и культура, также нуждающаяся в защите. Понятие экологии культуры утвердил более 30 лет назад академик A. С. Аихачев, зафиксировав, что в экологии есть два раздела: экология биологическая и экология культурная - «экологию нельзя ограничивать только задачами сохранения природной биологической среды. Аля жизни человека не менее важна среда, созданная культурой его предков и им самим. Сохранение культурной среды - задача не менее существенная, чем сохранение окружающей природы» $(\Lambda и$ хачев, 1980).

На рубеже XX-XXI вв. феномен «человеческой среды» как сферы исследовательского интереса обретает чрезвычайно широкий спектр смысловых коннотаций. Это может быть природная среда, «окультуренная» в той или иной степени, а также урбанизированная, технизированная, материально-предметная, бытовая среда. Среду 
можно интерпретировать в темпоральном и региональном аспектах, изучать в синхронной и диахронной проекции, а также представлять как социокультурный дискурс как историческую, национальную, конфессиональную, сословную, профессиональную, глобальную или локальную общность.

Аля человека XXI в. искусственная среда служит «естественной» средой обитания, составляя постоянный фон его повседневной жизнедеятельности. Окружающий мир предстает как его собственное творение, и потому в известной степени утрачивается оппозиция искусственного и естественного, внешнего по отношению к субъекту - наступает так называемый «конец природы» (Э. Гидденс). Аанный феномен исчезает в своей традиционно-классической онтологии «природы» как девственной среды. В реалиях современного глобального мира осталось чрезвычайно мало уголков «дикой природы» - природной среды в естественном состоянии, нетронутой человеком, где она воспроизводится, поддерживая саморегуляцию за счет внутренних процессов. Имеется в виду природная среда, которая в той или иной степени не подвергалась бы антропогенному воздействию в позитивном или негативном смысле, как, например, загрязнение. Эти территории доступны геолого-разведочным, географическим, иным научным экспедициям, туристам-экстремалам, работникам заповедников и заказников. Остальная же часть человечества знакома с природой, представленной в виде «культурного ландшафта» (О. Шлютер), в котором соединены природные и культурные объекты, т. е. географических зон, формируемых за счет «проекции», оставленной деятельностью человека в природном ландшафте.

На ином полюсе природно-антропогенного горизонта - «технизация» западной культуры. Она приобретает характер доминирующего процесса, создающего «новую природу» - рукотворную окружающую среду, так называемую техносферу. В ней техника, соединенная с наукой, осознается как единственная и фундаментальная основа цивилизации. Машинная цивилизация жестко ограничивает индивида, лишая его жизнеориентационного существования древности, при котором «идеальный человек», взаимодействуя с окружающей средой, максимально использовал свои потенции. Техника становится его судьбой и человек превращается в один из видов производственного сырья, в «постав», используя терминологию М. Хайдеггера.

Представляется, что начало экологических проблем современного общества, его всеобъемлющего техногенного кризиса было положено много раньше начала промышленных революций. Еще античность заложила первые камни в фундамент западной цивилизации, сформировав панлогизм, дуализм западного типа мышления. Тем не менее, рационализм античности был гармоничен, природа еще не находилась в жесткой оппозиции к человеку, а идея «человек есть мера всех вещей» еще не стала знаменем в деле ее завоевания и покорения. В эпоху Аревнего мира, в Средние века человек ощущал свое единство с природной средой, одухотворяя и обожествляя ее, воспринимах себя как органическую часть окружающего космоса.

Эпоха Возрождения коренным образом изменила этот естественный «космоцентризм». Возникает новая мировоззренческая парадигма, светское видение мира, ренессансная культура - гуманизм, в центре которого находится культ человека, ренессансный индивидуализм. Ренессансный герой становится демиургом и творцом, хозяином собственной судьбы, которая зависит теперь не от божественной воли, но от его собственных дарований, мужества и энергии. Совершается «огромная перемена, переход в прометеевскую эпоху, стоящую под знаком героического прототипа. Новый человек обращает свой взор на землю, в широкие дали по всей земле, а не на безгра- 
ничные высоты, как раньше... Новый человек стремится больше не к спасению души, а к владению миром. Он хочет быть господином на земле...» (Шубарт, 2000: 13). Аля создателя европейской культуры, «прометеевского» человека, олицетворяющего западный мир, нет ничего запретного: природа не принадлежит более космическому универсуму, но подвластна человеческому произволу. Его, «желавшего создать мир по собственному образу и подобию», В. Шубарт назвал «прометеевским» «по имени гордого титана, восставшего против богов». Этот «героический человек видит в мире хаос, который он должен оформить своей организующей силой... Миру ставятся цели, определяемые человеком» (Шубарт, 2000: 10-13).

Новая идеология - протестантизм - апеллирует к самому индивиду, к его личности, и потому учение о «личной вере» образует фундамент протестантской догматики. Концепция благодати и предопределения реабилитировала и освящала труд, меняла представление о человеке, его жизненной судьбе и возможности достичь спасения. Протестантская этика, создав эффективную систему норм и ценностей, регламентирующих хозяйственную практику и повседневный обиход, стала решающим фактором в развитии западноевропейского «духа капитализма». Именно эту сторону генезиса капиталистической системы отразил в своих трудах М. Вебер (эта тема рассматривалась им в работах «Протестантская этика и дух капитализма», «Хозяйственная этика мировых религий», «История хозяйства»).

Рационалистические интенции становящегося капитализма осознаются и рефлексируются культурфилософской мыслью. Это «естественная» философия Ф. Бэкона, аналитический научный метод исследования, стоявший у истоков опытной науки Нового времени, это когнитивизм Р. Аекарта, определивший логоцентрическую базу западноевропейской философии: «Я мыслю, следовательно, я существую». Рационализм картезианства резонировал с ходом әкономических и политических преобразований, с новыми алгоритмами общественного развития. Одновременно он закладывал основы механистического детерминизма и субстационального дуализма, противопоставлявшего друг другу мышление и материю, человека и природу. Искусственность, заданность параметров мышления и поведения прослеживалась во всех сферах жизни, начиная от организации системы управления, от регулярного войска и кончая отдельными әлементами быта.

Просвещение, развернувшееся с конца XVII в., провозглашало освобождение от духовной власти религии и схоластики: на смену мрачному средневековью пришла пора Разума. В социально-философских учениях развивается идея прогресса человеческого общества, основанного на принципах разума и общественного блага. Прогресс достигается усилиями людей, и человек предстает творцом и демиургом, призванном покорять природу, перестраивать социальные сферы и институты в соответствии со своими потребностями и нравственными идеалами. И одновременно здесь же звучит призыв «Назад, к природе», наиболее ярко выраженный в философии Ж.-Ж. Руссо. Пасторальные сюжеты и идиллические мотивы, мечты о простой и естественной жизни на лоне природы, возникшие как реакция на искусственную ритуализацию жизни, пронизывали повседневную культуру того времени.

Тем не менее, идея покорения, завоевания природы стала одним из краеугольных камней духовного фундамента общества модерна - трехсотлетнего этапа культуры Нового времени, - завершающегося, но все еще «незавершенного проекта» (Ю. Хабермас). Она получила дальнейшее развитие у И. Канта: разделяя оптимизм Просвещения в отношении разума, И. Кант по-иному формулирует и решает «проблему че- 
ловека»: разумность человека состоит в «свободе», в его независимости от законов природы. Вводя антиномию природы и человека, чувства и разума, Кант замыкает круг рациональности, разомкнуть который будет пытаться не одно поколение философов. Создание просвещенческой парадигмы, определившей вектор магистрального развития культурного универсума, было завершено. Результатом стал европейский идеал с его абсолютизированным антропоцентризмом и фетишизацией деятельности.

XIX в. - время динамичного промышленного развития, духа неуемной деловитости, апофеоз предпринимательства и торговли. Именно к этому веку, прошедшему под знаком индустриализации, относится становление техногенной культуры модерна - культуры, в которой техника, соединенная с наукой, осознается как единственная и фундаментальная основа цивилизации. В ней доминирует идеология технического оптимизма, которая питалась быстрым промышленным ростом, инновациями, демонстрирующими возрастающие технические возможности человека, повышением уровня жизни. Вера в научно-технический прогресс приобретает черты религиозной харизмы, оттенок истовости. Техника и технический прогресс становятся кумиром нового времени, отождествляются с идеей общественного блага.

Все дальше уходил человек от природы и от собственного естества, шел по пути, ведущим в никуда - по пути войны с природой, длившимся «от Гераклита до Хиросимы» (М. Серр). ХХ в. сделал это очевидным: это показали не только революции, две мировые войны, это продемонстрировали те сферы деятельности, которые еще в начале столетия олицетворяли надежды на лучшее будущее - наука, технический прогресс, развитие массовой культуры. Теперь все они были поставлены под подозрение: их результат мог быть амбивалентен. Так же был поставлен под сомнение априорно утвердившийся фундаментализм классической науки, принципы научного детерминизма, достоверного по своей природе научного знания: истина понималась как нечто окончательное и завершенное, следовательно, и все усилия исследователей следовало направлять на построение финалистской системы знания. Научный миф европейской Ауховной культуры возводился в статус всеобщей парадигмы, равно относящийся как к естественным, так и социально-гуманитарным наукам.

Слом классической парадигмы начался в XIX в. вместе с революционными открытиями в науке, влекущими трансформацию традиционной картины мира. В первую очередь это были теория относительности А. Эйнштейна и квантовая теория. Открытие дискретного изучения, квантов, исследование явлений радиации связаны с именами М. Планка, Э. Резерфорда, В. Гейзенберга, Н. Бора, они положили начало квантовой механике и изучению микроэлементов. Кризис в физике совпал с кризисом оснований математики. Революционными были и научные прорывы в биологии, где в результате исследования клетки было обнаружено существование генов, а позднее открыт генетический код - универсальный «язык» живых организмов. К достижениям гуманитарных наук, имевших широкий общественный резонанс, относятся психоанализ 3. Фрейда, аналитическая философия К. Г. Юнга, формулируемый ими концепт бессознательного, а также популярное в то время бергсонианство, гештальтпсихология, занимавшаяся изучением психологии творчества, механизмов восприятия. Сциентизм теряет господствующие позиции вместе с кризисом классической фундаменталистской эпистемологии, остановив тем самым триумфальное шествие «демона \апласа» - научной мифологемы европейской культуры.

Вместе с эмерджентностью и радикализмом происходящих перемен, с ростом солипсизма нарушается устойчивость среды обитания - на место предсказуемого, зна- 
чимого мира приходит мозаичное многообразие спонтанных вариаций, не поддающегося каким-либо прогностическим процедурам. Разрушаются еще вчера, казалось бы, стабильные основания, утрачивается органичность и целостность культурного универсума. Подобные процессы захватывают сферы политики, науки и искусства, социальных и национальных отношений. Возникает проблематика неравновесной среды, характеризующейся спонтанными проявлениями, усложнением структуры, возникновением новых качеств. Область описания, исследования состояний, далеких от равновесия, неустойчивых, нелинейных явлений, взаимодействия разноуровневых систем, приобретает все большее влияние. Ее методология получает распространение как в естественных, так и в общественных науках, включая, в частности, такие принципы, как вероятностный детерминизм, соотношения неопределенностей, принцип дополнительности и т. А.

Конец столетия - эпоха «пост»: «постмодернизм» и «постистория» разворачиваются в «постиндустриальном» пространстве. Отказ от рационализма и детерминизма, евро- и этноцентризма, как и всякой центрированности в принципе, пессимизм в отношении технического и социального прогресса характерны для ситуации постмодерна. И в то же время искусственная реальность, созданная новейшими технологиями, ее моделирование и трансформация, эстетическое экспериментирование составляют важнейший модус постмодернистской практики. Современное мировидение манифестирует отход от традиционного европейского принципа «гомоцентризма», когда человек Запада стремился подчинить себе природу, стать ее властелином. Критикуя классику, новые теории апеллируют к философскому иррационализму и интуитивизму, әстетике, в том числе экологической, возвращают права мифу, поэзии, сказке.

Так называемая «постнеклассическая парадигма» манифестирует отказ от классических, неизменных устоев, утверждает подвижность, изменчивость, динамичность самых общих аксиом, бывших некогда инвариантами. Постнеклассическая парадигма исходит из целостности, системности, многовариативности развития объективного мира, а также из относительности наших знаний. Практически только этот исследовательский подход репрезентативно формулирует верифицируемые подходы к самоорганизации сложных систем, описывает состояния динамических переходов, принципы взаимодействия порядка и хаоса. Именно эта методология способна к эффективному анализу открытых диссипативных структур, обладающих большим количеством степеней свободы, к которым относятся все системы как живой, так и неживой природы, объекты исследования гуманитарных наук, и потому эти методы должны получить приоритет в экологии.

Постмодернистская парадигма переводит акцент от статики к динамике, от субстанциональности к процессуальности, от автономии к когерентности; она делает упор на состояниях становления, перехода, взаимодействия. Именно она формирует качественно иные представления о мироздании как совокупности сложных нелинейных процессов, их стохастической динамики, плюрализму формообразования. В этом ключе требуют переосмысления основополагающие понятия живой природы, пространства, времени и материи. Теория материальных объектов зависит от контекста, в том числе временного - весь мир един, целое довлеет над частным.

Идеи и гипотезы, воспринимавшиеся ранее с недоверием, приобретают все большую значимость: физический мир подобен живому существу, такими же «живыми» являются вода и почва, земля и океаны. Они самонастраиваются, но являются ли они «чувствующими» системами, а может быть, «разумными»? Вдохновленные принци- 
пом неопределенности Гейзенберга, физики говорят о «свободе воли» частиц, о фундаментальном индетерминизме законов природы. В этом ряду находится и экзистенциально-экологическая гипотеза Геи, выдвинутая в 1970-е годы биологом Аж. Аавлоком, которая гласит: атмосфера, океан и почва вместе с биосферой представляют собой некое единое образование. Его параметры настолько точно поддерживают необходимый метаболизм, что напоминают живую сущность. Гипотеза Геи продолжает и развивает идеи русских космистов, теории К. Циолковского, В. Вернадского, А. Чижевского.

Примеры можно множить, но суть их одна: механистическая причинность, одномерность сознания, линейный эволюционизм исчерпали себя в исторической перспективе. Они требуют замены, жизненно необходимой для будущего развития: «Научиться мыслить по-новому, чтобы сохранить жизнь на нашей планете», - одно из актуальных требований, девиз, сформулированный в манифесте Пагуошского движения. Современная наука трансформируется: разочарованность в системе институционально легитимированного знания дезавуирует тотальный логоцентризм классики. Это же относится и к проблеме научной истины, которая определяется теперь в контексте социокультурных референций. На место жесткого детерминизма, универсальной научной истины приходят более тонкие связи дискретного характера, многомерность и многовариантность научных сценариев, провоцирующих неопределенность, парадоксальность и неверифицируемость результатов научного поиска.

Мышление, построенное на принципе всеединства, берущее свое начало от анаксагорова принципа «все во всем», иная, не аристотелевская логика, оказываются созвучны современности. Идея «все во всем» формирует новое понимание природы и человека, обосновывая актуальность экологической тематики. Физики, представители других естественных наук обращают свой взгляд к философским проблемам, ищут новые пути и подходы. И в этом важную роль призваны сыграть такие сферы, как эстетика или же восточная религиозная философия. Н. Бор, открывший принцип дополнительности, предлагает в этой связи «обратиться к совсем другим областям науки, например, к психологии или даже к особого рода философским проблемам; это те проблемы, с которыми столкнулись такие мыслители, как Будда и Аао-Цзы, когда пытались согласовать наше положение как зрителей и как действующих лиц в великом храме существования» (Бор, 1961: 35). Н. Бор берет своей эмблемой изображение Великого Предела.

Запад все больше поворачивается к Востоку, а его современная рефлексия напоминает алогизм восточной религиозной философии. Так, традицией древней китайской культуры задан единый жизнеобразующий принцип: инь - ян, Великий Предел (тайцзы). В соответствии с ним мир состоит из двух начал, он двуедин, амбивалентен. Единство целого обусловлено взаимодополняемостью сторон. Начала не противостоят друг другу, но взаимоположены, взаимосвязаны. Более того, они пронизывают Аруг друга, как свет и тьма, жар и холод, покой и движение. «В жизни существует зарождение, в смерти существует возвращение», говорится в даосском трактате Чжуанцзы (Иаоцзы, 2000: 290). Их данность обеспечивает постоянство, равновесие. Где-то больше инь, где-то больше ян. Великий Предел играет роль абсолюта, регулирующего жизнь и движение во Вселенной: сначала движение идет в одну, потом в другую сторону. Начала инь и ян равноправны, и потому пульсация, ритм - абсолютный закон вселенной. Они взаимоуравновешены: «один раз инь, один раз ян и есть Путь (Аао). Следуя этому, идут к добру». 
На Востоке отсутствует конфронтационная дуальность мира. Наоборот, господствуют взгляды, что все противоположности - суть нашего неведения, все различия относительны. Мышление изначально целостно, толерантно, образно. Нет остановки, но есть движение. Каждый миг неповторим, и ничто не повторяется в вечном потоке перемен. Естественно, это связано с идеей Пути: «Аао туманно и неопределенно. ОАнако в его неопределенности и туманности содержатся образы. В его туманности и неопределенности содержатся вещи. В его глубине и неясности содержится жизненная сила. Эта жизненная сила и есть Истина» (Иаоцзы, 2000:153).

Мир изначально совершенен, гармоничен, поэтому его не нужно переделывать. Активность человека по радикальному преобразованию природы искдючена. Надо лишь, по даосскому идеалу, уподобиться природе, следовать ей в большом и малом. Об этом же говорится и в буддийском учении. «Истина и Будда всегда с тобой, они вокруг тебя, надо только уметь их найти, увидеть, узнать и понять. Истина и Будда везде и во всем - в пении птиц, в нежном шелесте листвы, ... в умиротворенной тиши озера, в сказочной красоте природы, в разумной сдержанности церемониала, в очищающей и просветляющей силе медитации, наконец, в радости труда... Нужно уметь жить, познавать жизнь, радоваться ей, воспринимать ее во всем богатстве, многообразии и красоте» (Васильев, 2006: 615-616), - так формулируется взгляд на мир в доктрине чань-буддизма. Широко известна эстетика дзен. Это искусство интерьера, костюма, икебана; это эстетика боевых искусств, японских садов и чайной церемонии. Помимо собственно искусства она подчиняет законам прекрасного самые разные стороны жизни.

Природа гармонична, и лишь человеческие страсти, людское невежество мешают осознать эту гармонию. Суть как буддийского, так и даосского пути - в достижении непротиворечивого существования. Важен принцип недеяния - увэй - действия, отвечающего естественному ритму:

«Человек берет за образец Землю.

Земля берет за образец Небо,

Небо берет за образец Аао,

Аао берет за образец естественность»

(цит. по: Аукьянов, 2000: 188).

Таков же и восьмеричный путь буддизма: правильный взгляд, намерение, речь, действие, образ жизни, усердие, внимание и сосредоточение. Выбрав любой из этих путей, человек может придти к конечной цели: слившись с космосом, достичь единства со Вселенной и, вернувшись к истокам, погрузиться в Нирвану.

Все больше внимания привлекает восточный принцип «природоцентризма» ( «натуроцентризма»), восточной эстетики, где человек как бы погружается в бесконечность вселенной. В новом контексте постмодерн воспринимает и рефлектирует специфику корейской, японской эстетической чувственности, эстетическое чувство в традиционной китайской эстетике. Здесь доминирует ментальное действие трансрациональной природы - слияние чувства и ландшафта, которые определяются природно-вегетативным комплексом или же цветовой семантикой - это эстетика природных форм и ритмов: эстетика моря и океана, эстетика дистьев и цветов, эстетика ветра, эстетика белого или желтого цвета и т. п. Запад постепенно обретает мудрость, позволяющую человеку вернуться к природе, ощутить и воспринять благотворное богатство чувственного знания.

Говоря об экологии культуры, А. С. Аихачев в своей известной статье обращается к городской среде, к архитектуре. Рассматривая правила и нормы русского градост- 
роительного искусства (Иихачев, 1980), он обращает внимание на необходимость сохранения этих памятников истории, отмечая большую воспитательную роль культурного наследия. Аействительно, накапливая исторический нарратив, генерируя культурные практики, урбанизированная среда может рефлектироваться в качестве феномена культуры, имеющего как эмпирический, так и глубокий философский смысл. Основные характеристики городской среды как лона, которое рождает разнообразные культурные формы, ее курьтуртрегерская роль хорошо известны еще с античности. Кроме того, она наделена смыслами, является специфическим пространственным текстом, выполняет идейную, идеологическую функцию. Одной из важнейших социальных функций города как организованного пространства является необходимость гармонизации общественного организма, для чего требуется создание комфортной среды обитания, в том числе формирование публичных пространств. Важен также эстетический аспект: эстетизация окружающей человека среды означает ее гуманизацию.

Коммуникативным пространством становятся открытые городские пространства, там, где встречаются знакомые и незнакомые друг с другом жители данных мест, случайные прохожие, туристы. Эта территория позволяет людям найти точки соприкосновения, некий «общий язык тротуара» (Аж. Ажейкобс). Фактически эти пространства выполняют функцию наблюдательной площадки, на которой люди могут видеть друг друга, знакомится с поведенческими паттернами, получать опыт общения. В плане социализации это особенно ценно для молодых людей, для которых публичные пространства служат полигоном в отработке коммуникационных навыков, своеобразной школой социализации. Информационный эффект публичности универсален, люди в городе могут многое узнать об окружающих, «просто глядя друг на друга» $(\Lambda$. Аофланд).

Х. Арендт трактует публичность как пространство встреч свободных граждан и выработки ими, в результате обсуждения, некоторой согласованной точки зрения на волнующие всех вопросы общественной жизни. Она рассматривает публичную сферу не как медийное, виртуальное пространство информационного обмена, а как реальную сферу непосредственного взаимодействия людей - «предстояние других, которые видят, что мы видим, и слышат, что мы слышим, удостоверяет нам реальность и нас самих» (Арендт, 2000: 66).

Х. Арендт, как и большинство исследователей публичности, связывает эту сферу с появлением демократии, и потому с публичной жизнью, по ее представлениям, ассоциируется античная греческая агора, римский форум. Аействительно, греческая агора в максимальной степени удовлетворяла условиям «предстояния». Эклессию Афин, являющуюся высшим органом полисной власти, характеризовала исключительная Аля Аревнего мира суверенность: никто не мог ограничить ее компетенцию, так как единственным методом воздействия на собрание являлось убеждение, и потому демагоги, владевшие ораторским искусством, становились народными вождями.

Полис интерпретируется Х. Арендт как дискурсивное пространство, а античный грек - как человек политический: сам полис конституируется непосредственно его свободными гражданами: «не Афины, а афиняне были полисом». На агоре античный грек проводил большую часть своего дня, заполняя это время привычными и потому будничными занятиями: торговлей, едой, общением, обсуждением насущных вопросов, получая и, в свою очередь, делясь информацией. Жизнь регламентировалась законом, который «был действительно «стеной закона» и создавал как таковой прост- 
ранство полиса; без этой стены мог стоять город в смысле скопления домов для совместной жизни людей, но только не город-государство как политическая общность» (Арендт, 2000: 82-83).

Закон и его «стены» гарантировали автономность сфер и делали возможным их существование, определяли правила и условия перехода из частной сферы в сферу публичности. Только здесь, становясь человеком политическим, индивид получает свое подлинное существование - может быть воспринят другими, делается увиденным и услышанным. Существенной отличительной характеристикой публичности, по Арендт, является реальность, вытекающая из всеобщей увиденности и услышанности, а также общность мира, которая интегрирует и одновременно дифференцирует собравшихся.

Контекст взаимной визуализации, «предстояния» в терминологии Х. Арендт имеет значение для современного понимания городской среды. Это не только публичное взаимодействие, сотрудничество или конфликт, но в первую очередь - опыт экспонирования, выставленности на всеобщее обозрение. В эссе «Исток художественного творения» М. Хайдеггер определил задачу архитектора, которая состоит в создании поля открытости в повседневном мире (Хайдеггер, 2008). Разрыв, просвет в текстуре мира позволит увидеть этот мир в его цельности и «несокрытости»- между тем как сокрытость мира создается рутиной частной повседневной жизни. Идеализированное представление об урбанистической среде предполагает, что именно она позволяет выстраивать диалог, отвечает человеческой потребности быть вместе. Здесь берут начало процессы интеграции разрозненных, анонимных горожан в одно городское или же районное сообщество, оказывая влияние на процессы личной и групповой идентификации.

Существует, однако, и прямо противоположный тренд. Горожане, как правило, друг с другом не знакомы: мир города, в отличие от деревни, от небольших поселений, по сути своей анонимный, особенно, если речь идет о мегаполисах. Неизвестность провоцирует высокие риски: находясь среди массы незнакомых людей, горожане могут испытывать всевозможные фобии или стресс от огромного количества визуальных контактов. Одной из важнейших характеристик городского пространства является безопасность. Она во многом обеспечивается самими горожанами, а не правоохранительными органами: люди присматривают друг за другом и таким образом начинает работать социальный контроль публичного пространства. Э. Гидденс, И. Гофман предлагают объяснять типологию взаимодействия городских жителей, используя понятие гражданского невнимания - особенности, присущей коротким контактам «на бегу». Проходящие мимо быстро обмениваются взглядами, а затем, подходя ближе, смотрят в сторону, - таким образом они демонстрируют друг другу, что у них нет причины быть враждебными. При этом необходимо избегать любого жеста, который мог бы быть истолкован как навязчивый. Подобное поведение имеет основополагающее значение в обыденной жизни, создавая комфортный фон взаимодействий среди большого количества повседневных контактов.

Аля современной городской среды характерны тенденции, связанные с возрастающей мобильностью и виртуализацией, консюмеризмом. Новейшие информационные технологии трансформируют понятие «место»: оно определяется через событийный трафик, то есть через происходящие в данном месте события. Мобильность в современном мире достигается во многом за счет феномена дистанционной коммуникации. Распространение таких технологий, как телефон и телевидение делает наше местопо- 
ложение амбивалентным: позволяет людям, находящимся в одной точке пространства, находиться одновременно в другой его точке. Это множественные формы «воображаемого присутствия» (Аж. Ури) реализуются благодаря различным объектам и изображениям, гаджетам и экранам, позволяющим взаимодействию осуществляться как сквозь, так и внутри социального пространства. Само местоприбывание субъекта становится в ситуации виртуального контакта не принципиальным - оно локализуется виртуально.

Аругая, набирающая силу тенденция - консюмеризм, превращение городских пространств в пространства потребления, где доминируют потребительские практики. Пространства потребления создают лишь иллюзию общности, одновременно избавляя от потребности в коммуникации. Потребители пользуются общей территорией, какой являются концертные или выставочные залы, туристические курорты, места для занятий спортом, торговые пассажи, рестораны и кафетерии. По своей сущности все они должны позиционироваться как пространства, предназначенные Аля общения разнообразных групп и слоев, тем не менее, они предназначены лишь для тех, кто готов и может практиковать предлагаемый тип потребления.

Разрушающе воздействуют на коммуникацию так называемые «высокомерные» (Р. Сеннет, 3. Бауман), неприветливые пространства - слишком большие, официозные, предназначенные для официальных торжественных церемоний, парадов и т. п. Они кажутся пустыми и неприветливыми, вызывают эмоциональный дискомфорт, ощущение потерянности. Так, античный Рим, стоявший у истоков европейской цивилизации, утверждал свое господство не только мечом, но и архитектурой, выполнявшей идеологическую и пропагандистскую функции. О мощи и величии империи свидетельствовали помпезные городские сооружения: грандиозность и масштабность стала характерной чертой римского мира - мира циклопических архитектурных форм, воплощающих идею Вечного города. В европейской культуре идея Вечного города была неоднократно повторена с помощью архитектурной символики: во втором Риме - Византии, в классицизме европейских столиц, а также на американском континенте - в Вашингтоне, в центре американской столицы.

Традиционно методология анализа, ракурс наблюдения в классической науке соотносился с «отстраненным» наблюдением, ограничивался рассмотрением только визуально-пластической панорамы городской среды - т. е. городской ландшафт рассматривался извне, отдаленный от своего исследователя, как бы «заключенный в рамку». Город таким образом превращался в «городской пейзаж», и только в такой ситуации, в ситуации «пейзажа» (и при выполнении прочих необходимых условий), феномен мог претендовать на статус исследуемого объекта, предмета «незаинтересованного» созерцания. Постклассика меняет положение наблюдателя - он непосредственно включается в наблюдаемый объект, исчезают рамки, сокращается до минимума дистанция - возникает «эффект присутствия». Мир оживает в потоках звуковых, визуальных, одорических впечатлений и, поскольку реальный водоворот городской жизни создает текучую среду, то необходим феноменологический подход, мягкие методы «понимающего присутствия» для обеспечения всей полноты культурологической рефлексии.

Урбанизированная среда представляет собой тип пространства, наполняющего жизнь людей особым смыслом - она превращает своих жителей в горожан, генерирует специфически городские практики, модели поведения, стереотипы мышления. Это, безусловно, больше, чем простое проживание в многоквартирных домах или 
пользование общественным транспортом. Понятие культуры городской среды, ее экология содержит ценностно-ориентированный смысл, важный для современного общества - и потому город должен быть не каменными джунглями, но «форумом, где возможно общение и единение с другими людьми».

В современных условиях феномен гармоничного и комфортного городского пространства оказывается чрезвычайно востребованным, более, чем полвека назад. Урбанистическая среда содержит ценностно-ориентированный смысл, важный для современного общества - и потому город должен быть не каменными джунглями, но «форумом, где возможно общение и единение с другими людьми», местом разнообразных интересов». Подобная постановка вопроса связана с концепцией «права на город», как пространства, принадлежащего проживающим здесь людям, сформулированной А. Аефевром.

Одной из важнейших социальных функций организованного пространства является необходимость гармонизации общественного организма, для чего необходимо создание комфортной среды обитания, в том числе формирование публичных пространств. Некомфортные для горожан города несут угрозу стабильности общества. И наоборот, дружественный ландшафт, позитивные визуальные и эмоциональные впечатления позволяют выстраивать диалог, служат целям «социального демпфинга». Комфортная городская среда, которая создается путем внедрением специальных технологических, социальных, градостроительных решений, способна в значительной степени смягчать имущественное неравенство горожан, устранять жесткую зависимость качества жизни людей от уровня их доходов.

Экологическая культура в известной степени преодолевает исходные, базисные позиции постмодернистской методологии - принцип деконструкции, расщепления универсума. Она выдвигает положения о концептуальной целостности, гармоничном сочетании человеческой деятельности и природы, бережного сохранения памятников истории. Основные характеристики экологической культуры - ее гармоничность и функциональность, и именно на них необходимо ориентироваться в разработке отдельных тем глобального феномена «человеческая среда».

\section{СПИСОК АИТЕРАТУРЫ}

Арендт, Х. (2000) Vita activa, или О деятельной жизни. СПб. : Алетейя. 437 с.

Бек, У. (2001) Общество риска. На пути к другому модерну. М. : Прогресс-традиция. 304 с.

Бор, Н. (1961) Атомная физика и человеческое познание. М. : Издательство иностранной литературы. $151 \mathrm{c.}$

Васильев, А. С. (2006) История религий Востока. М. : КАУ. 706 с.

Гейзенберг, В. (1987) Шаги за горизонт. М. : Прогресс. 368 с.

Гидденс, Э. (2004) Ускользающий мир: как глобализация меняет нашу жизнь. М. : Весь Мир. $120 \mathrm{c}$.

Маоцзы (2000). Обрести себя в Аао. М. : Республика. 447 с.

Аихачев, А. С. (1980) Экология культуры // Памятники Отечества. № 2. С. 10-16.

Аукьянов, А. Е. (2000) Аао-Цзы и Конфуций: Философия Аао. М. : Восточная литература PAH. 383 c.

Хайдеггер, М. (2008) Исток художественного творения. М. : Академический проект. 528 с.

Шубарт, В. (2000) Европа и душа Востока. М. : Русская идея. 443 с.

\section{REFERENCES}

Arendt, X. (2000) Vita activa, ili O deyatel'noj zhizni. [Vita activa and condition humaine]. Sankt-Peterburg, Aletejya. 437 s. (In Russ.) 
Bek, U. (2001) Obshchestvo riska. Na puti k drugomu modernu. [Risk Society: Towards a New Modernity]. Moscow, Progress-tradiciya. 304 s. (In Russ.)

Bor, N. (1961) Atomnaya fizika i chelovecheskoe poznanie [Atomic Physics And Human Knowledge]. Moscow, Izdatel'stvo inostrannoj literatury. 151 s. (In Russ.)

Vasil'ev, L. S. (2006) Istoriya religij Vostoka. Moscow, KDU. 706 s. (In Russ.) Russ.)

Gejzenberg, V. (1987) Shagi za gorizont [Schritte über Grenzen]. Moscow, Progress. 368 s. (In

Giddens, Eh. (2004) Uskol'zayushchij mir: kak globalizaciya menyaet nashu zhizn' [Runaway World: How Globalization is Reshaping Our Lives]. Moscow, Ves' Mir. 120 s. (In Russ.) Russ.)

Laoczy (2000). Obresti sebya v Dao [To find myself in the Tao]. Moscow, Respublika. 447 s. (In

Lihachev, D. S. (1980) Ehkologiya kul'tury. Pamyatniki Otechestva. № 2. S. 10-16. (In Russ.)

Luk'yanov, A. E. (2000) Lao-Czy i Konfucij: Filosofiya Dao. Moscow, Vostochnaya literatura RAN. 383 s. (In Russ.)

Hajdegger, M. (2008) Istok budozhestvennogo tvoreniya [Ursprung des Kunstwerkes]. Moscow, Akademicheskij proekt. 528 s. (In Russ.)

Shubart, V. (2000) Evropa $i$ dusha Vostoka [Europe and the soul of the East]. Moscow, Russkaya ideya. 443 s. (In Russ.)

Аата поступления: 03.05.2017 2.

Козьякова Мария Ивановна - доктор философских наук, профессор, профессор кафедры философии и культурологии ФГОУ ВО Высшее театральное училище (институт) им. М. С. Щепкина. Адрес: 109012, Россия, г. Москва, ул. Неглинная, д. 6/2. Тел.: +7-916-347-79-73. Эл. адрес: markoz@yandex.ru

Kozyakova Maria Ivanovna, Doctor of Philosophy, Professor, Department of Philosophy and Cultural Studies, M. S. Schepkin Higher Theatre School (Institute). Postal address: 6/2, Neglinnaya St., Moscow, Russian Federation, 109012. Tel.:+7-916-347-79-73. E-mail: markoz@yandex.ru

Аля иитирования:

Козьякова М. И. Экологический тренд как вектор развития [Электронный ресурс]// Горизонты гуманитарного знания. 2017, № 3. URL: http://journals.mosgu.ru/ggz/article/view/519 (дата обращения: АА.мм.гггг.). DOI: 10.17805/ggz.2017.3.9 